\title{
JEAN MCWHIRT PINKLEY, 1910-1969
}

\section{Chester A. Thomas}

$\mathrm{T}^{\mathrm{H}}$ HE NATIONAL PARK Service lost a valuable employee, and archaeology lost one of its foremost women scientists in the death February 18 of Jean M. Pinkley. Jean was stricken at her desk at Pecos National Monument on February 7 and was hospitalized in Santa Fe. She was flown to Houston, Texas, on February 9 for open chest surgery to repair a ruptured aorta, and considerable hope was held out for her recovery after the surgery. However, the end came quickly at 1:30 a.m., February 18, 1969.

A body of uniformed National Park Rangers stood honor guard at her funeral which was held in Tucson, Arizona, February 21, where N.P.S. associates from throughout the Service and representatives from learned institutions gathered to pay their last respects. Although Mrs. Pinkley had spent most of her notable career at Mesa Verde National Park, she had been assigned to the Southwest Archaeological Center for the past three years. Her task for the Center during this period was to excavate and stabilize Pecos Mission near Santa Fe, New Mexico. She was working hard at this job when death overtook her.

Jean M. Pinkley was born in Miami, Arizona, August 6,1910, but, as a child, she moved with her family to Pennsylvania. Her father was a U. S. Army doctor, and her early years were spent on many Army posts throughout the United States. She attended various high schools and upon graduation entered the University of Arizona. She graduated (cum laude) in June 1933, with a degree in Anthropology and Archaeology. In 1936 she received her Master's degree in archaeology from the same institution.

After receiving her training in dirt archaeology under Dr. Emil Haury at the University of Arizona, she elected to enter the National Park Service to lend a hand in interpreting Southwest prehistory to the millions of visitors to this area so rich in the remains of an ancient people.

Jean was first assigned to Mesa Verde National Park in 1939 as a Museum Assistant, selected from the Civil Service Register of Junior Park Archaeologists. In 1942 she married Addison Pinkley, son of the renowned "boss" of the Southwestern National Monuments. In 1943 she left the Service to join her husband who was in the Navy. Addison was on the submarine "Squalus" which bolstered the sinking morale of the American public by sailing into Tokyo Harbor and sinking many merchant ships. On the second venture into the jaws of the enemy, the Japanese were successful in destroying the submarine with the loss of all on board.

Following her husband's death in 1943, Mrs. Pinkley devoted her life to her job. So well did she perform her work that she was selected for the Mesa Verde assignment over a number of qualified men. As Chief of the Interpretive Division, her duties covered all facets of interpretation, including acting in an advisory capacity to the Superintendent, supervising research pertinent to interpreting the Park and its features, operation of museums, trailside and roadside exhibits, and integrated visitor-service programs, the excavation and stabilization of prehistoric ruins, and planning for future development of the interpretive program of the Park. In April 1966, she was called to Pecos National Monument to head the five-year excavation and stabilization program there.

While at Mesa Verde Mrs. Pinkley built up one of the finest interpretive programs in the National Park Service and directed this program through the most profound changes in the history of the Park. When an era encompassing 50 years suddenly came to an end after World War II, the National Park Service's Mission 66 at Mesa Verde was planned to completely change the pattern of development for use of the Park. Mrs. Pinkley successfully met the challenge of the myriads of reorganization changes inherent in the transition.

In the period 1946-1959, she played a dominant role in the development of the archaeological museum in Mesa Verde utilizing the most advanced techniques in museum exhibit methods with great skill. This made possible the presentation of a significantly broader spectrum of the archaeological story of the Mesa Verde Cliff Dwellers and their predecessors than had previously been accomplished. This museum has served millions of visitors during the past two decades and is the outstanding installation of its kind among more than $200 \mathrm{mu}$ seums of the National Park System. 


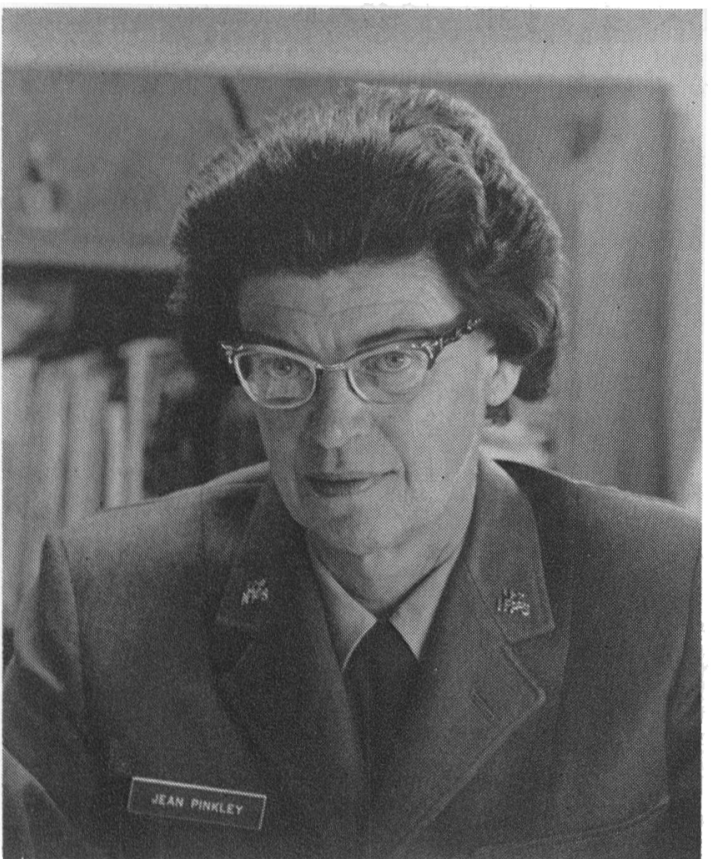

JeAN MCWhiRT Pinkley

Mrs. Pinkley was a major contributor to the planning of the Wetherill Mesa Archeological Project, a joint undertaking of the National Park Service and the National Geographic Society. Costing over a million dollars, it is the largest single archaeological excavation and research program ever attempted by the National Park Service. It is estimated that 20 volumes will be required to record the scientific knowledge recovered, and more than 80 articles in periodicals have been published thus far.

During the five years the Project was underway, Mrs. Pinkley served as the Superintendent's advisor on interpretive and research matters, and she played a major role in guiding the program to successful completion.

Under Jean's professional guidance, unique archaeological ruins stabilization methods and techniques were developed respresenting pioneering work in a new field. She interested the Texas Refinery Company in expending $\$ 100,000$ on research to find a product that would preserve fragile adobe and sandstone masonry walls without changing their color or character. The company came up with "Pencapsula" an encapsulating agent that, while it is not a panacea for all ruins deterioration problems, does hold a great deal of promise in preserving antiquities in the field. Later, she successfully treated the ancient adobe walls of Pecos Mission with the material.

Mrs. Pinkley was instrumental in planning new visitor tour routes in the Park designed to present archaeological sites in proper chronological order. In addition to a thorough and meticulous knowledge of the field of Western and Southwestern archaeology, she possessed an intuitive grasp of practical human psychology and behavior as well. These qualities enabled Mrs. Pinkley during these years at Mesa Verde to advance the cause of education and conservation, a primary concern of the National Park Service in 20th-century America.

In April 1966, she was selected to direct the Pecos Project near Santa Fe, New Mexico. There she undertook the job of threading out the important and fascinating interpretive story inherent in the most important of the Spanish missions in New Mexico.

The excavation and stabilization of Pecos Mission proved one of the most difficult and complex archaeological puzzles an archaeologist might be called upon to face. Jean attacked the job with her usual devotion and struggled through the maze of contradictory documentary sources and the maddening jumble of archaeological evidence. By determinedly pursuing elusive clues, she was able eventually to outline a large early church which contemporary observers had recorded but which historians had written off as a myth.

The A.D. 1600 church at Pecos has proved to be unique in New Mexico Mission architecture in that it was far larger and architecturally more complex than the later structure. It is probably the only example of its kind north of Mexico. Evidence of burning of the A.D. 1600 church probably confirms that it was destroyed in the A.D. 1680 Pueblo rebellion. The A.D. 1700 church, which is partially preserved today, was built on the ruins of the fine earlier church which few people thought ever existed.

The interpretive story that the Mission has to tell has been greatly enriched by Jean's work, and a fascinating chapter in the history of New Mexico has been brought to light.

In recognition of her outstanding career and her success as a woman in the Federal Service, the First Lady, Mrs. Lyndon B. Johnson, invited Mrs. Pinkley to have lunch with her at the White House on March 22, 1966. About a dozen other women from other professions in the United States and foreign countries were also 
honored at this meeting. Mrs. Pinkley was the only Federal Career woman present. Other guests included Anne Morrow Lindberg, the Mayor of the City of Cork, Ireland, and Madame Curie. On November 14, 1966, Mrs. Perle Mesta, on behalf of the First Lady, invited Mrs. Pinkley to a luncheon at the Pan American Building in Washington. In October, 1967, Jean was given the Department of the Interior's Meritorious Award "in recognition of outstanding professional archaeological services and contributions to interpretive programs of the National Park Service."

Mrs. Pinkley coauthored a publication on archaeological excavations in Mesa Verde National Park in 1952 and contributed an article on the turkey and the Pueblos to the volume of Memoirs of the Wetherill Mesa Project in 1965.

Jean Pinkley was highly successful in supervising men. Usually it is difficult for men to take direction from women, but Jean succeeded because she insisted on carrying her full share of the load.

Those who shared her activities have extraordinary memories of this remarkable woman. They remember Jean descending a 200-ft. rope to inspect isolated ruins and climbing out again with hands blistered and arms and legs covered with rope burns; yet she was a very feminine person, an assured speaker, a gracious hostess, an intelligent friend and colleague.

Travelers and tourists to the Southwest will in the future enjoy prehistoric ruins and learn their significance as they go their ways through the desert land, and whether or not they are aware of it, they will owe a great debt of gratitude to this courageous person who devoted her life to the preservation, study, and interpretation of the rich cultural heritage of the American Southwest.

National Park Service

Globe, Arizona

April, 1969 